http://dx.doi.org/10.11646/phytotaxa.166.1.7

\title{
Studies on Wrightoporia (Basidiomycota) from southern Brazil
}

\author{
MAURO C. WESTPHALEN ${ }^{1,2}$, MATEUS A. RECK ${ }^{1} \&$ ROSA MARA BORGES DA SILVEIRA ${ }^{1}$ \\ 'Programa de Pós-Graduação em Botânica, Universidade Federal do Rio Grande do Sul, Av. Bento Gonçalvez 9500, 91501-970, \\ Porto Alegre, RS, Brazil.Email: maurowestphalen@yahoo.com.br, mateus_reck@yahoo.com.br, rosa.silveira@ufrgs.br \\ ${ }^{2}$ Current address: Instituto de Botânica, Av. Miguel Estefano 3687, 04301-90, São Paulo, SP, Brazil.
}

\begin{abstract}
In recent surveys of polyporoid fungi from Rio Grande do Sul State, southern Brazil, some interesting resupinate specimens belonging to the genus Wrightoporia were found. Wrightoporia araucariae is described as new, based on the fragile, whitish basidiomes which grow exclusively on Araucaria angustifolia; and W. bracei is recorded for the first time from Rio Grande do Sul State. In addition, W. efibulata is synonymized to Wrightoporia bracei based on collected specimens and herbarium material. The species are described, illustrated and discussed, and an identification key to the neotropical species of Wrightoporia is provided.
\end{abstract}

Key words: Wrightoporiaceae, xylophilous fungi, Russulales, taxonomy

\section{Introduction}

The genus Wrightoporia Pouzar belongs to the family Wrightoporiaceae Jülich (Larsson 2007) and, according to Mycobank databases (Robert et al. 2005), about 40 species are currently accepted in the genus. It is characterized by basidiomes with a tubular hymenophore and finely ornamented, amyloid basidiospores. The hyphal system is usually dimitic with clamped generative hyphae, but hyphae with simple septa can also occur. Also, the skeletal hyphae are often dextrinoid. Wrightoporia belongs to the order Russulales, which is distinct among the Agaricomycetes due to the ornamented amyloid basidiospores and the presence of a gloeopleurous hyphal system (Miller et al. 2006).

So far, five species of Wrightoporia are known from Brazil: W. avellanea (Bres.) Pouzar (Gerber \& LoguercioLeite 2000), W. bracei (Murrill) I. Lindblad \& Ryvarden (Loguercio-Leite \& Wright 1991), W. cremea Ryvarden (Ryvarden 1987), W. porilacerata C.L. Leite, A.L. Gerber \& Ryvarden (Loguercio-Leite et al. 1998) and Wrightoporia tropicalis (Cooke) Ryvarden (Rick 1959).

During recent surveys in Rio Grande do Sul State, a resupinate species of Wrightoporia was found growing exclusively on dead logs of Araucaria angustifolia (Beltol.) Kuntze and herein is described as new. Wrightoporia bracei, previously known only from Santa Catarina State in Brazil, is recorded for the first time from Rio Grande do Sul State. In addition, a new synonymy is proposed for Wrightoporia efibulata I. Lindblad \& Ryvarden, based on type studies.

\section{Material and Methods}

Specimens were collected in areas of Atlantic rainforest (Dense Ombrophilous Forests) and Araucaria forest (Mixed Ombrophilous Forests) in Rio Grande do Sul State, southern Brazil, between 2007 and 2010, dried and deposited at the ICN Herbarium of the Federal University of Rio Grande do Sul. Specimens from the Botanical Museum of the University of Oslo (O) and the U.S. National Fungus Collection (BPI) were used for comparison. The specimens were examined according to Núñez \& Ryvarden (2001). For microscopic analysis, hand-cut sections of the basidiomes were mounted on microscope slides with a drop of $3 \% \mathrm{KOH}$ solution and $1 \%$ aqueous 
4. Pores large, 1-3 per mm, often lacerate

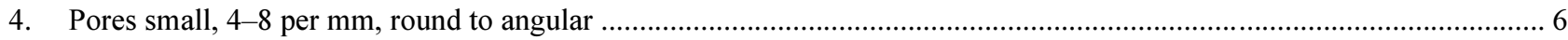

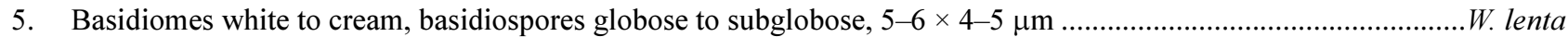

5. Basidiomes cream to pale brown, usually with darker patches, basidiospores subglobose to broadly ellipsoid, $3.5-4.5 \times$ $2.5-3.5(4) \mu \mathrm{m}$ W. avellanea

6. Basidiomes soft and fragile, margin mycelioid, pores 4-6 per mm, basidiospores globose to subglobose 3-4 $\times 3-3.5 \mu \mathrm{m}$, on gymnosperms (gen. Araucaria)

6. Basidiomes tough, margin rounded, pores $6-8$ per mm, basidiospores ellipsoid $3-3.5(4) \times 2.5-2.8 \mu$ m, on angiosperms ... W. neotropica

7. Basidiomes fleshy when fresh, pores $1-3$ per mm, hyphal system monomitic W. porilacerata

7. Basidiomes corky to soft when fresh, pores $3-5$ per $\mathrm{mm}$, hyphal system di-trimitic 8

8. Pileus surface reddish brown, pores irregular, sometimes elongated, basidiospores ellipsoid $(3-3.5 \times 2 \mu \mathrm{m})$

W. brunneo-ochracea

8. Pileus surface cream to pale ochraceous, pores regular, round to angular, basidiospores subglobose $(3.5-4 \times 3 \mu \mathrm{m})$ W. cremea

\section{Acknowledgments}

The authors would like to thank the staff of the Botanical Museum of the University of Oslo (O) and the U.S. National Fungus Collection (BPI) herbaria for the loan of specimens and Larissa Trierveiler-Pereira for assistance in the scanning electron microscopy technique. CAPES and CNPq (Brazil) are acknowledged for financial support.

\section{References}

Backes, A. (1999) Condicionamento climático e distribuição geográfica de Araucaria angustifolia (Bertol.) Kuntze no Brasil II. Pesquisas - Botânica 49: 31-51.

David, A. \& Rajchenberg, M. (1987) A reevaluation of Wrightoporia and Amylonotus (Aphyllophorales, Polyporaceae). Canadian Journal of Botany 65: 202-209. http://dx.doi.org/10.1139/b87-027

Gerber, A.L. \& Loguercio-Leite, C. (2000) Polyporoid wood-rotting fungi (Basidiomycetes) II - new records from southern Brazil. Mycotaxon 76: 175-185.

Larsson, K.-H. (2007) Re-thinking the classification of corticioid fungi. Mycological Research 111: 1040-1063. http://dx.doi.org/10.1016/j.mycres.2007.08.001

Lindblad, I. \& Ryvarden, L (1999) Studies in neotropical polypores. 3. New and interesting Basidiomycetes (Poriales) from Costa Rica. Mycotaxon 71: 335-359.

Loguercio-Leite, C., Gerber, A.L. \& Ryvarden, L. (1998) Wrightoporia porilacerata, a new species of pore fungi from southern Brazil. Mycotaxon 67: 251-255.

Loguercio-Leite, C. \& Wright, J.E. (1991) Contribution to a biogeographical study of the austro-american xylophilous polypores (Aphyllophorales) from Santa Catarina Island, SC., Brazil. Mycotaxon 41: 161-167.

Miller, S.L., Larsson, E., Larsson, K.-H., Verbeken, A. \& Nuytinck, J. (2006) Perspectives in the new Russulales. Mycologia 98: 960-970. http://dx.doi.org/10.3852/mycologia.98.6.960

Mota, F.S. (1951) Estudos do clima do Estado do Rio Grande do Sul, segundo o sistema de W. Köppen. Revista Brasileira de Geografia 13: 275-284.

Núñez, M. \& Ryvarden, L. (2001) East Asian polypores. Synopsis Fungorum 13: 1-168.

Rick, J. (1959) Basidiomycetes Eubasidii in Rio Grande do Sul - Brasilia. 3. Hypochnaceae, Clavariaceae, Craterellaceae, Hydnaceae. Iheringia, Bot. 5: 125-192.

Robert, V., Stegehuis, G. \& Stalpers, J. (2005) The MycoBank engine and related databases. http://www.mycobank.org (Accessed 07 February 2014).

Ryvarden, L. (1987) New and noteworthy polypores from tropical America. Mycotaxon 28: 525-541.

Ryvarden, L. (2000) Studies in neotropical polypores 7. Wrightoporia (Hericiaceae, Basidiomycetes) in tropical America. Karstenia 40: 153-158.

Thiers, B. (2010) Index Herbariorum: A global directory of public herbaria and associated staff. New York Botanical Garden's Virtual Herbarium. http://sweetgum.nybg.org/ih/ 